European journal of American studies

Special Issue: Media Agoras: Islamophobia and Inter/ Multimedial Dissensus

\title{
Inter/Multimedial Constructions of Islam in Post-9/11 TV Series: The West Wing and 24
}

\section{Brigitte Georgi-Findlay}

\section{(2) OpenEdition}

\section{Journals}

Electronic version

URL: https://journals.openedition.org/ejas/16203

DOI: $10.4000 /$ ejas. 16203

ISSN: 1991-9336

Publisher

European Association for American Studies

Electronic reference

Brigitte Georgi-Findlay, "Inter/Multimedial Constructions of Islam in Post-9/11 TV Series: The West Wing and 24", European journal of American studies [Online], 15-3 | 2020, Online since 22 September 2020, connection on 08 July 2021. URL: http://journals.openedition.org/ejas/16203 ; DOI: https:// doi.org/10.4000/ejas.16203

This text was automatically generated on 8 July 2021 .

Creative Commons License 


\title{
Inter/Multimedial Constructions of Islam in Post-9/11 TV Series: The West Wing and 24
}

\author{
Brigitte Georgi-Findlay
}

1 Since The West Wing (NBC, 1999-2006), the genre of the political drama series has become a proliferating format for fictional engagements with American politics (domestic and foreign) and with the U.S. presidency (24, Commander in Chief, Scandal, House of Cards, Designated Survivor), vice presidency (Veep), or the office of secretary of state (Political Animals, Madam Secretary). ${ }^{1}$ Especially after 9/11, public narratives about Islam and Islamophobia have resonated also within these series. However, while there is an extensive body of scholarship on the impact of $9 / 11$ on representations of Islam in American media (see, for example, Morey and Yaqin 2011; Alsultany 2012; Alsultany 2014) and in political thriller series such as Homeland (Showtime, 2011-2020), these narratives do not figure prominently in most of the scholarly discussions on political drama series.

Many of these shows feature a built-in problem. Since they focus on national security, international relations, and the business of politics, their engagement with Islam and representations of Muslims is framed almost solely by issues of U.S. national security and terrorism (foreign and domestic). One may surmise that this is why the creators of these series, in order to avoid offense and to offset critique, seem to have resorted to a set of strategies which Evelyn Alsultany has termed "simplified complex representations" serving as the typical "representational mode of the so-called postrace era" (Alsultany 2014: 144). As Alsultany has explained, she is "concerned with the standardization of 'positive,' sympathetic representations of Arab and Muslim identities" since these "seemingly positive representations... have helped to form a new kind of racism, one that projects antiracism and multiculturalism on the surface but simultaneously produces the logics and affects necessary to legitimate racist policies and practices" and to "project the United States as an enlightened country that has entered a postracial era" (Alsultany 2012: 16). Although I share some of Alsultany's 
concerns, I find the representations of Arabs, Muslims and Muslim countries in some of these shows more contradictory and complex. As multimedial texts that are receptive to intermedial aesthetics, television series encourage multiple and contrasting readings and ideological positionings (see Mehring and Furlanetto, "Introduction"; Rippl 3, 12). I read political drama series consequently as multivocal texts that, in the words of Frank Mehring and Elena Furlanetto, "may display dynamics of internal accord and disaccord" (see "Introduction"). These dynamics can be related to the serial character of televisual storytelling, to the particular institutional and political contexts in which the series emerge, and to long-standing tensions between inclusionist and exclusionist perspectives on the American nation.

3 In the following, I will focus on this polyvocality regarding representations of Arabs, Muslims, Muslim countries, and terrorism particularly in The West Wing and 24 (Fox, 2001-2010). As the first TV shows to engage, albeit in differing ways, with the emerging government policies and public discourses in the wake of 9/11, both contributed in significant ways to the framing of narratives about Islam and Islamophobia in the first decade of the twenty-first century. I will explore how polyvocal narratives are brought across not only on the level of plot and dialogue, but also by way of aesthetic strategies (camerawork, soundtrack, split screens and multiple-frame compositions) and intermedial references (newscasts, satellite imaging, cell phones, allusions to the interaction of politics and media). I will show how these strategies supply additional information and textual layers that complicate viewers' processes of meaning-making and contribute to in-text dissensus and ideological ambivalence.

4 Although the scholarly engagement with the politics of The West Wing and 24 might seem dated in 2020, when the polarization of American politics and the tribalization of American culture appear to have reached an unprecedented high point, it may make sense to bring into view again the political and cultural transformations of the late 1990s and early 2000s (even before 9/11). Both shows emerged in a climate of increasingly partisan politics, defined by "culture wars," battles over the meaning and consequences of globalization, by the challenges of redefining U.S. foreign policy after the end of the Cold War, and by a controversial national election in 2000. They appeared at a time when the televisual landscape was undergoing shifts from broadcasting to narrowcasting, from a mass audience to niche audiences, from mainstreaming to streaming. In the chronology of these shifts presented by Amanda D. Lotz, both shows belong to what she has termed the "multi-channel transition period," in between the network era and today's "post-network era" (ix-x). As network shows, both reflected the pressure to avoid offense while offering innovative programming. As transitional shows, they partook in changes underway in televisual modes of storytelling and audience address, in an industrial context where there was now a broader range of viewing audiences "thriving on specialty, distinction, and niche taste" (39). Both shows segued into new viewing practices (initially mostly defined by DVD) that broke from linear programming schedules and that pushed the boundaries between episodic and serial forms of storytelling (see Lotz 73-4; Mittell 53).

The West Wing has received credit for establishing the genre of the political drama series and for offering a lofty vision of public service at a time when real-life official politics and politicians had arguably lost their authoritative power. The show immersed its viewers into the daily flow of political work behind the scenes in a White House perpetually confronted by domestic and foreign policy dilemmas that loosely 
referenced real-life historical or current events. In the two seasons of The West Wing that aired before 9/11, terrorism featured as a marginal plot device. If it became an issue at all, terrorist threats to the U.S. could be seen emerging equally from homegrown sources such as white pride (S1E17, S2E2) or eco-terrorism (S2E12) as from countries identified with Islam (Syria in S1E2). The opening of Season 3 then had to be postponed because of 9/11. On October 3, 2001, a quickly drafted, stand-alone episode was aired which indirectly referenced $9 / 11$ and stirred considerable controversy among viewers and critics. While some felt that "the episode revealed that it was possible to debate terrorism "in a sensitive, sensible and intelligent way"' (McCabe 98) and that its style of discussion surpassed the quality found on news channels, others denounced it as preachy, "overly didactic" (Takacs 54) and unable "to conceive the complexities of the Middle East in anything other than Western terms" (Steven Aoun, qtd. in McCabe 99). Stacy Takacs has argued that the episode "pathologized terrorism, promoted 'American innocence,' and disciplined its audience to embrace social authority as a condition of 'American' identity" (47).

Called "Isaac and Ishmael," this episode serves as my first example to illustrate how a televisual text creates a sense of in-text dissensus that may lead to more ambivalent ideological projections than those suggested, for example, by Aoun and Takacs. The episode features two storylines. While one storyline focuses on the White House hosting a visiting group of racially diverse high school students, in a parallel story an Arab American staffer is suspected of working with Islamic extremists planning an attack in the U.S. The White House is in lockdown mode. Two parallel, intertwined storylines present, on the one hand, the conversation that White House staffers and the President have with the visiting students (a classroom situation), and on the other the racial profiling and interrogation of the Arab American. The two storylines challenge each other. One of them can be read as Orientalist, the other as post-Orientalist or antiracist.

7 In the first storyline, the White House staffers stage a teach-in for a captive audience of students and viewers alike. Each of the fictional characters represents a different position on the relations between Islam, U.S. culture, U.S. foreign policy, and terrorism which were at the center of American public narratives about 9/11. Deputy White House Chief of Staff Josh Lyman compares Islamic extremists to the KKK ("the Klan gone medieval and global") and calls Islamic fundamentalism a "cultural wasteland." The Jewish-American communications director Toby Ziegler (Richard Schiff) sees the terrorists on the same level as Nazis ("When you think of the Taliban, think of the Nazis") while deputy communications director Sam Seaborn (Rob Lowe) is convinced that terrorism is rooted in eleventh-century Islamic culture and is thus inherently foreign to America. All of the voices imply that Islam, terrorism, and the opposition to pluralism and freedom are un-American, alien, and external to the U.S. Cultural studies scholar Stacy Takacs has therefore argued that these voices all relate terrorism to a violent cultural disposition rather than to concrete political grievances (53). However, these grievances are addressed by the personal aide to the president, African American Charlie Young (Dulé Hill), who sees a link between poverty and terrorism and draws connections to domestic forms of racial violence. In addition, Josh Lyman acknowledges the legitimacy of grievances about U.S. foreign policy when he suggests that "it's probably a good idea to acknowledge that they have specific complaints. I hear them every day-The people we support, troops in Saudi Arabia, sanctions against Iraq, support of Egypt." Since all of these voices somehow aim to represent the wide and 
contradictory range of public narratives about 9/11, I would argue, this storyline of the episode may have left viewers to ponder multiple, implicitly also contradictory, political perspectives.

8 The second storyline, which focuses on the interrogation of the Muslim staffer, exposes the interrogators' racist disposition and brings into view the aggression that Muslims in the U.S. have been subjected to before and after 9/11. It shows what happens "when Americans abandon tolerance in the pursuit of security" (Takacs 50) and suggests that threat cannot be read from ethnicity or religious affiliation (Holland 91). The contradiction between the two storylines is mediated not only on the level of dialogue, but is also made visible by way of casting choices and staging. Thus a visual pan of the students visiting the White House reveals their diversity-male and female, African American, white, Hispanic, Asian. Also, the interrogation of the Muslim staffer is staged in dark tones, evoking a sense of claustrophobia and paranoia. The fact that a respected fictional character, Chief of Staff Leo McGarry (John Spencer), is chosen to lead the interrogation in a manner that seems to be out of character for him, underscores the disruptive nature of the event. The two conflicting stories thus illustrate how the show deliberately stages an in-text dissensus by exposing the contradictions within the American national identity discourse, between an inclusionist civic and an exclusionist racialized nationalism, a tension that Trevor and Shawn Parry-Giles have identified as central to The West Wing as a whole (17).

9 As critics have pointed out, the episode does not encourage any real engagement with Islam as a religion (Spigel 244) but rather foregrounds politicized forms of Islam that may threaten U.S. national security. Yet I would argue that the episode, like the series as a whole, stages relevant discussions rather than simply "staging an illusion of political debates" (Takacs 47). The polyvocality that the episode displays may be more facile than that usually displayed in The West Wing where Steadicam tracking shots follow staffers walking and talking through the halls, discussing and deliberating political issues from all possible sides, thus making visible the workings of a democracy (McCabe 63-4). By framing 9/11 as an attack on U.S. freedom and pluralism and deeming critical questions of past U.S. policies mostly off-limits, the episode may represent the discursive limitations and pressures hovering over the first days after 9/11. However, as Trevor and Shawn Parry-Giles have argued, it "offered a different discourse than those offered by President Bush and other public officials. It presented a dialogic rhetoric that symbolically invited participation and disputation" about the threats confronting the U.S., although it "still located the power to define and respond to national trauma in the White House" (160). They suggest that with its "pluralistic polyvalence" (166) the episode "self-reflexively questions the ethnocentrism inherent in the conventional American mantra about freedom and democracy" (163). Especially the second plotline "questions the simplistic civic nationalism at work in political culture following $9 / 11$ and gives voice to the racialized and gendered quality of U.S. nationalism" (164).

10 As a whole, I would argue, The West Wing discussed the politics related to Muslims, Muslim Americans and Muslim countries in a way that could lead to informed debates, taking into account multiple perspectives by utilizing a large ensemble cast (of admittedly limited diversity with regard to gender and race). Most of the time this takes place in the form of dialogues and arguments between the main characters. Thus one character argues: “The U.S. Constitution defends religious pluralism. It doesn't 
reduce all of Islam to fanaticism" (S3E14), stirring a debate about the complexity of the constitutional relationship between politics and religion. Characters discuss issues and ventilate ideas, casting different knowledges and perspectives on Islam, Islamic cultures and geographies in the form of argument and dissent. The show especially stages debates about the relation of Islam to Western conceptions of state and society. Recurring storylines decry Islamic law as a source of oppression, especially of women. Thus, the female White House Press Secretary C.J. Cregg responds in an uncharacteristically emotional way to the news that Saudi school girls had died in a fire because they had been prevented by the religious police from leaving a burning building as they were not seen to be appropriately dressed (S3E19). The series here references a real-life event that drew international attention in March 2002.

11 Yet the show also comments critically upon the idea of a U.S. intervention into Muslim countries' internal affairs, thus engaging with the real-life public political discourse on the invasion of Iraq as it unfolded in 2002 and 2003. At the end of Season 3 (aired in May 2002), fictional President Jed Bartlet (Martin Sheen) sanctions the covert assassination of the defense minister of the fictional Islamic Republic of Qumar who allegedly sponsored a planned attack within the U.S. In the course of seasons 4 and 5 this leads not only to cover-ups and guilt on the part of the president, but also to controversial debates about the logic of toppling a "moderate Islamic regime" (S5E1) and about the problematic role of U.S. policies in the Middle East (S5E9, S5E10). By Season 5 (aired from late 2003 through early 2004) it has become increasingly difficult for the Bartlet administration to assess whether a protest in an Islamic country (to be witnessed on TV news screens) is part of a fundamentalist or a nascent democratic movement (see, for example, S5E10). In its representations of a fictional U.S. policy in the Middle East, the series mediates real-world discussions both by inventing entire countries such as Qumar and referencing real places, events (such as the plight of the Saudi school girls mentioned above) and real-life U.S. relations with Muslim countries. But it is not very consistent here. Although the fictionalization of Qumar may be interpreted as an instance of Orientalism in the way the series imagines the country as a foreign "other," one could also read it as a dramatic serial device to critically address real-life U.S. foreign policy involvement in the Middle East that includes the support of Saudi Arabia, the issue of state-supported terrorism, questions of human rights (also with relation to gender) and the U.S. invasions of Afghanistan and Iraq.

In fact, by the fall of 2003, The West Wing created a counter-narrative to the real-life invasion of Iraq earlier that year, imagining an alternative U.S. policy in the Middle East. Although the dramatic action takes place in Gaza and involves the IsraeliPalestinian conflict, the series recreates a threat situation that resembles that of the U.S. after 9/11, discussing whether the administration should react (like the Bush administration) with retaliatory strikes, despite insufficient intelligence. In the end, President Bartlet resists the calls for military action also within his staff (S5E21, S5E22, S6E1, S6E2). While the series here very obviously references the Bush administration's invasion of Iraq, it uses this imaginary counter-scenario also to address another reallife conflict by reenacting a Middle East peace conference at Camp David. It thus reminds viewers of the historical role of the U.S. as a peace broker that brought Israelis and Palestinians to a table. In this context, the series has the characters render a political debate that considers as many perspectives as possible. Viewers are involved in the process of meaning-making by being presented with a multimedial array of 
dialogues, conversations and images, including TV newscasts, that heighten understanding, but that also leave much space for interpretation, consent and dissent.

Ambivalences are generated also by the way The West Wing embeds or buries stories about Islam and Islamophobia within narratives about U.S. political cultures. Thus, in some plotlines, the correlation made within the administration between Islamic countries and terrorism is revealed to be false and home-grown sources of terrorism and danger need to be considered (see S3E18). While this diversification of the "enemy" in surprising plot turns may be explained by TV seriality's inherent need for variation, it still comes across as a deliberate political choice made by the series creators to engage critically with real-life Islamophobic tendencies. In Season 5, for example, proselytizing Christian missionaries are seen to be more of a problem for the administration than Islamic law (S5E9). Here, the administration is confronted with the hatred against Arab American immigrants. It reacts to Islamophobic attacks on naturalization ceremonies by having the events held in the White House (S5E3). We also hear a Supreme Court justice prepare a brief regarding the racial profiling of Arab Americans, in which the plight of Muslims is compared to that of Japanese Americans after Pearl Harbor (S5E7). In Season 7 the story of a religiously motivated suicide bomber is embedded within episodes that center on the way the religious right in the U.S. is trying to manipulate a presidential campaign. By pairing these stories, the series creates an equation between Islamic fundamentalism and Christian fundamentalism as similar phenomena. It thus picks up the critique of racial profiling and Islamophobia in the U.S. that had been voiced in the "Isaac and Ishmael" episode opening Season 3. These micronarratives seem to disrupt other messages that tend to conflate Islamic countries and terrorism. Although the show at times does not seem to go beyond binary "notions of either patriotism or victimization" (Alsultany, "Representations" 150), and although it tends to conflate Arab ethnicity and the religion of Islam, it nevertheless challenges these binaries and conflations in the way it intertwines multiple stories and discourses.

14 The West Wing clearly foregrounds language and reflects on language use in its attempt to bring across multiple, often contradictory perspectives and political positions. Yet, it is not only dialogues and conversations that challenge viewers, confronting them with an excess of information. Meaning-making is additionally complicated by "a constant interplay between multiple televisions tuned to the different news channels, full of sound bites, spin, and spectacle" (McCabe 69). TV newscasts and press conferences held in the White House, in which conflicting positions both within the administration and within the various media outlets come to the fore, show how the series includes and uses references to the print and news media to illustrate the processes and problems of a democratic discourse. These may include spin, image control, and the framing of issues by the administration. But they also include the conundrum that the administration often only learns about events by watching CNN (which reflects the particular mediascape and its impact on U.S. politics in the early 2000s). White House staffers and administration are seen to be in constant interaction with media that both supply needed information and complicate political work. These media include the print media, broadcast news channels, and talk shows on radio and TV. For the viewer, these intermedial references may add to the impression of an in-text dissensus, for example in S5E10, when both fictional characters and viewers watch newscasts of protests unfolding in the Middle East. Here the series stages a discussion held by White House staffers as well as former and present U.S. presidents around the links between 
monarchic systems, Islamic law, colonialism, U.S. policy and democracy in the Middle East. In the end, the issues are left open for viewers to ponder.

Subtextual commentary adding to in-text dissensus may at times also be provided by non-diegetic music. Thus S5E1 ends with a song ("Sanvean" sung by Lisa Gerrard) played over a montage of scenes, all picturing unrelated dramatic personal and political events that unfold simultaneously and that include both the kidnapping of President Bartlet's daughter and a U.S. airstrike on terrorist training camps in a fictional state in the Middle East. While the storyline draws on viewers' sympathy for the President's family and demonizes an abstract "terrorist" enemy, the mournful song that evokes associations with "Oriental" music provides an affective counterpoint, lamenting the loss of lives and human suffering on all sides.

All of these examples may support the argument that the series stirs a sense of in-text dissensus not only on the level of plot and dialogue, but also on the level of aesthetic techniques and intermedial references. In addition, as McCabe and Frame have shown, these techniques underwent a significant change over the program's run. Frame argues that the series' politics "evolved in response to the seismic, almost simultaneous shocks to its liberal ethos" provided by the transition from the Clinton to the Bush administration and by 9/11 (117-118). He identifies a change from representing "America's confident post-Cold War attitude towards incursions in foreign lands" (124) to a "re-evaluation of the president's role in the post-Cold War political environment" (125) and a post-9/11 narrative in which the president's movement over to the "dark side" (of the "war on terror") is visualized, for example, by changes in lighting (131-137). Other medial innovations include the use of the handheld camera in the episodes dealing with the Israeli-Palestinian conflict discussed above (S5E21, S5E22, S6E1, S6E2), illustrating "the inability of the president to control unpredictable global events in the post-9/11 environment" and "lending not only a feeling of (manufactured) liveness to proceedings, but also an overwhelming sense of uncertainty and fear" (139). As an "aesthetic shorthand for "breaking news," Frame suggests, the shaky mobile camera may also reflect changes in the media environment after 9/11 where news and entertainment conflated in unprecedented ways (140). All in all "the changes in visual style and tone can be understood as a subtle critique of Bush's 'war on terror"' and as a complication of the Bush administration's "'us' and 'them' dichotomy" (171).

17 Hence, The West Wing can be read as a text that leaves space for interpretation and ideological ambiguity with regard to the representation of Islam, Islamophobia, Muslims and Muslim countries. This ambiguity, which leads to the impression of an intext dissensus, may have various sources. It may reflect the contradictions within an American national identity discourse. It can be related to the mechanisms of a "serially unfolding television narrative" (Kelleter 75) which is dynamic and evolving, "favoring ongoing variations, increasing entanglements, and ever deeper complications" (60). It may also be related to the pressures working within network television where a show might want to appeal to both sides of the political aisle at first and then cater to a more liberal niche audience. As McCabe has observed, the series initially attempted to balance political debate, also to "stave off accusations that the show had too liberal a slant" (13). In some cases (as in the "Isaac and Ishmael" episode), polyvocality was the result of deliberate staging by the series creators who may have wanted to create a complex text, also with regard to capturing the complexities of the political issues that 
were addressed. In addition, changes in the show's politics over its run need to be taken into account. All of this may work against the argument that these representations of Islam, Muslims and Muslim countries operate in the service of "racist policies and practices" (Alsultany, "Representations" 144).

Watching the first season of Designated Survivor in 2016, viewers might have been struck by the strong critical focus this season laid on Islamophobic politics and violence within the U.S. while it recreated a 9/11 moment. This is especially interesting since the $A B C$ show is regarded as a successor series to 24 (with Kiefer Sutherland as lead actor in both programs) which has been accused of supporting, if not creating, Islamophobia. 24 is both a political drama and an action drama centering on Sutherland's character Jack Bauer, an agent of the U.S. government's Counter Terrorist Unit (CTU) who in each season races a ticking clock to subvert impending terrorist attacks on the United States and the various presidents during a twenty-four-hour state of emergency. The series is thus part of the genre of "terrordrama" that was increasingly popular after 9/11 (McCullough 2), reflecting and creating a permanent sense of mistrust and paranoia. People are never what they seem to be, and it takes a whole season to understand the identity of the perpetrators. Since the main subject of 24 is the threat to U.S. national security, Muslims, Muslim Americans, Islamic cultures and geographies are addressed only within this context. Yet the series creators have clearly tried to counter critiques of supporting Islamophobia by resorting to a number of strategies that fit what Evelyn Alsultany has identified as "simplified complex representations" (Alsultany, "Representations" 144-149) and that could also be found in The West Wing.

Among these are, first, the rotation or diversification of the identity of the enemy threatening U.S. national security. Thus, the threats may come from Balkan villains (Season 1), Mexicans (Season 3), Africans (Sesason 7), Russians (Season 8), or American patriot groups (Season 7). Although it seems that Arabs or Muslims represent the majority of terrorist suspects, if not perpetrators, in this series, most of the scripts reveal white male government authority or executives in the oil and private security industries as motive forces behind the plots. However, as in The West Wing, Islamic countries are connected to political disorder, Arab ethnicity and the religion of Islam are conflated.

As a "highly serialized" (Lotz 73) text, 24 uses ambiguities and complications to suspend the stories' final outcomes. Multiple layers of truth are only gradually revealed. This specific form of serial storytelling also impacts viewers' ideological meaning-making processes. Thus there are so many plot twists and turns, so many people involved in the plots against America, that the stereotype of the Arab/Muslim terrorist "other" is neutralized. Viewers are coopted into producing "connections between Middle Easterners, Arabs, Islam, and terrorism" (Takacs 91), only to learn that these suspects are "merely pawns or a front for Euro-American or European terrorists. The identity of the enemy is thus flipped" (Alsultany, "Representations" 146). For every "foreign" enemy there is a "domestic" one. For example, in Season 2, after suspicion had fallen on an Iranian bridegroom, it is his blonde-haired, blue-eyed American bride who is revealed to have colluded with terrorists, for reasons that are not quite clear (S2E10). "Good" characters may be misrecognized as "bad" and vice versa. The show consequently performs a balancing act, representing ethnic and religious difference but seemingly refraining from value judgments and leaving viewers to do the work. As 
Stacy Takacs has argued, the show's "penchant for visual and narrative excess provides the necessary space for the entertainment of multiple points of view and political perspectives, but it does so in a way that devolves responsibility onto the atomized viewers and fans of the show" (92). Takacs further contends that the show implicates viewers "in the construction of meaning" (90) in a manner that makes them "complicit in the construction of the ideological norms the show advances" (91).

21 A second strategy is that for every "bad" Arab or Muslim there is a "good" Arab or Muslim American character ready to fight for the U.S. Islam is "portrayed as inspiring American patriotism as opposed to inspiring terrorism" (Alsultany, "Representations" 145). In Season 2, an Imam is heard condemning any crimes committed in the name of Islam (S2E12). In Season 4 two Arab American brothers who have been subjected to Islamophobia speak out against the conflation of Islam and terrorism and assist Jack Bauer in his fight against the bad guys (S4E13). Yet the show also briefly breaks through the binary of either patriotism or victimization in a scene where an Arab perpetrator becomes the victim of Black Islamophobia (S4E5). The problematic distinction between "good" and "bad" Arab/Muslim is then illuminated when the Arab/Muslim leader of a terror cell explains his actions by pointing to injustices perpetrated by the U.S. against "his people." We hear his warning: "Renounce your imperialist policies" (S4E19) or "pay the price for your government's policy.... Renounce your policies of imperialism and interventionist activities" (S4E20). When he is captured and interrogated, his grievances are acknowledged by Jack Bauer who asks him what he wants to change for "his people." The man answers: "I already have" (meaning he has set a plot in motion to destroy the U.S.) and he adds: "Besides, your president sees me only in one dimension. Evil." Jack Bauer answers: "As you see us" (S4E22). Nevertheless, even if the imperial character of U.S. foreign policy is briefly acknowledged, the grievances the man has with the U.S. are articulated so vaguely and with so much hatred that his complaints lose credibility and legitimacy.

A further strategy that creates ideological ambivalence is the series' tendency to implicate the Washington political establishment as a potential source of threat. The U.S. government (including its Counter Terrorist Unit) is revealed as morally flawed, ineffective, even corrupt. Government agents like Bauer are subjected to government injustice and are, in the perspective of the Washington establishment, as expendable as the enemy "other." Hence, Muslims and Islamic countries have no monopoly on conspiracies and violent plots in this series. Although viewers, especially in the wake of 9/11, may have become used to the entertainment of associations between Islam, Arabs, Arab Americans and terrorism, the show rather disabuses them of these too simple associations. It counters its own "Islamophobic reputation" (McCullough 43) by creating a "polysemic, variable, and often incoherent" (75) text that is "riddled with ideological contradictions" (77).

In fact, Islamophobia is only a minor part of the culture of suspicion and paranoia that is recreated and evoked in a series where no character can be trusted, not even within the CTU, and things are never what they seem. 24 evokes this sense of paranoia and disorientation on an aesthetic level by resorting to medial techniques associated with live broadcasts. As McCullough has suggested, 24 borrows "techniques from action news, reality television, and sports coverage... in order to intensify audience engagement" (1). The use of handheld, shaky cameras creates a "live effect" that "contributes to a sense of urgency," but also reinforces the disorientation and distrust 
evoked by the constant plot twists and turns that throw characters and viewers offcourse. Split screens and multiple frames encourage "comparisons between different characters' reactions to the same events, revealing important information about them" (50), and yet viewers are still left with the work to actively "stitch the various pieces of information together into a meaningful whole" (Takacs 89). Other media producing additional information are cell phones and screens showing images from satellites and surveillance cameras. These videographic elements are supplemented by "text printed on screens including digital time clocks and readouts; and... endless images of screens" (McCullough 63). This excess of visual information adds to the "entertainment of multiple points of view and political perspectives" (Takacs 92) and "makes identification difficult" for the viewer (McCullough 63).

Additional textual layers that may intensify in-text dissensus are brought across by the use of lighting, color, soundtrack and music. In 24, sound design and music create parallels between the characters' and the viewers' search for information (Takacs 89). However, as McCullough has rightly argued, music "rarely contradicts the goal of establishing character motivation and story development" (66). Music and soundtrack may support the visual information by creating "stereotypical associations between characters or locations and musical themes" (66-7). "Oriental" music often underscores the sense of difference and threat tied to spaces and characters, including Muslim spaces such as cities and mosques, for instance in S2E11. However, there are also a few instances in which music may provide a subtextual counterpoint to what is witnessed on screen. Thus, in S4E5 'Oriental' music lends a note of tragedy to the death of an Arab American that had colluded with a terrorist group. Musical associations implicitly undercut the triumphalist impulses that may have been encouraged by the storyline.

Hence, both The West Wing and 24 can be read against the grain-and against the more critical readings provided by some scholars-as contradictory texts that both reflect and expose Islamophobia. Since the storylines about Islamic cultures and geographies are never unrelated to contexts of national security, they may reflect the automatism of the links created between Islamic countries and threats to national security. At the same time, American Islamophobic behavior within the U.S. is exposed as implicitly unAmerican. Both The West Wing and 24 can be read as texts that feature in-text dissensus not only on the level of plot and dialogue, but also on the level of aesthetic strategies and intermedial references that heighten viewers' understanding but that also leave much space for interpretation, consent and dissent. As polyvocal serial texts that leave viewers to ponder a range of perspectives and political positions, they are ideologically more ambivalent than is suggested by scholars who see the series advancing "a new kind of racism" or contributing to a "multicultural post-race illusion" (Alsultany, "Representations" 144). In their ambivalence they rather seem to expose long-standing tensions within American identity discourses between a civic inclusionist and a racialized exclusionist nationalism that particularly came to the fore in the days after 9/11. Both shows reflect, but at times also transcend, the discursive norms and limitations of their time, the first decade of a new century, and of their industrial contexts. Both emerged in a mediascape in which HBO, cable and DVDs began to define the production and reception of TV shows before streaming and streaming platforms appeared. However, in its multimedia textual structure, especially 24 already manifests and anticipates shifts in the mediascape that have come to define the industrial contexts and forms of televisual storytelling that we know today. 


\section{BIBLIOGRAPHY}

Alsultany, Evelyn. "Representations of Arabs and Muslims in Post-9/11 Television Dramas." The Colorblind Screen. Television in Post-Racial America, edited by Sarah Nilsen and Sarah E. Turner, New York UP, 2014, pp. 140-166.

---. Arabs and Muslims in the Media: Race and Representation after 9/11. New York UP, 2012.

Frame, Gregory. The American President in Film and Television: Myth, Politics and Representation. Peter Lang, 2014

Guggenheim, David, creator. Designated Survivor. Kinberg Genre, The Mark Gordon Company, Baer Bones, ABC Studios, 2016-2019.

Hall, Barbara, creator. Madam Secretary. Barbara Hall Productions, Revelations Entertainment, CBS Television Studios, 2014-2019.

Holland, Jack. "'When You Think of the Taliban, Think of the Nazis': Teaching Americans '9/11' in NBC's The West Wing." Millennium: Journal of International Studies, vol. 40, no. 1, 2011, pp. 85-106.

Kelleter, Frank. "“Whatever Happened, Happened': Serial Character Constellation as Problem and Solution in Lost." Amerikanische Fernsehserien der Gegenwart. Perspektiven der American Studies und der Media Studies, edited by Christoph Ernst and Heike Paul, transcript, 2015, pp. 57-87.

Lotz, Amanda D. The Television Will Be Revolutionized. Second edition, New York UP, 2014.

Lurie, Rod, creator. Commander in Chief. Battleplan Productions, Steven Bochco Productions, 2005-2006.

McCabe, Janet. The West Wing. Wayne State UP, 2013.

McCullough, John. 24. Wayne State UP, 2014.

Mittell, Jason. Complex Television: The Poetics of Contemporary Television Storytelling. New York UP, 2015.

Morey, Peter and Amina Yaqin. Framing Muslims: Stereotyping and Representation after 9/11. Harvard UP, 2011.

Parry-Giles, Trevor and Shawn J. Parry-Giles. The Prime-Time Presidency: The West Wing and U.S. Nationalism. U of Illinois P, 2006.

Rippl, Gabriele. "Introduction." Handbook of Intermediality. Literature - Image - Sound - Music, edited by Gabriele Rippl, DeGruyter, 2015, pp. 1-31.

Sorkin Aaron, creator. The West Wing. John Well and Warner Bros, 1999-2006.

Surnow, Joel and Robert Cochran. 24. Imagine Television, Real Time Productions, Teakwood Lane Productions, 20th Century Fox Television, 2001-2010.

Spigel, Lynn. "Entertainment Wars: Television Culture after 9/11." American Quarterly, vol. 56, no. 2, June 2004, pp. 235-270.

Takacs, Stacy. Terrorism TV. Popular Entertainment in Post-9/11 America. UP of Kansas, 2012. 


\section{NOTES}

1. I want to thank the volume editors and the reviewers for their critical comments and very helpful suggestions.

\section{ABSTRACTS}

Since The West Wing (NBC, 1999-2006), the political drama series has been a proliferating format for fictional engagements with American politics. Georgi-Findlay focuses on how The West Wing and 24 (Fox, 2001-2010) engage public narratives about Islam and Islamophobia, arguing that the shows go beyond what Evelyn Alsultany has termed "simplified complex representations" by creating contradictory, multivocal texts that display dynamics of internal disaccord. Representations of Arabs, Muslims and Muslim countries are embedded within storylines that challenge each other. Especially The West Wing stages discussions that can lead to informed debates, reflecting and exposing the contradictions within the American national identity discourse between an inclusionist civic and an exclusionist racialized nationalism. In both series, polyvocal narratives are brought across not only by intertwining multiple discourses, but also by way of aesthetic strategies and intermedial references that supply additional textual layers, complicating viewers' processes of meaning-making and contributing to in-text dissensus and ideological ambivalences. Both series thus can be read against the grain, as contradictory, multivocal texts that both reflect and expose Islamophobia.

\section{INDEX}

Keywords: Orientalism, Multimedia, Islamophobia, Hollywood, Historical Film

\section{AUTHOR}

\section{BRIGITTE GEORGI-FINDLAY}

Brigitte Georgi-Findlay is professor of North American Studies at the TU Dresden. Her publications include two monographs on Native American literature and one on The Frontiers of Women's Writing: Women's Narratives and the Rhetoric of Westward Expansion (University of Arizona Press). In recent years, she has focused on Western films and Western television series, and has worked and published on recent series such as Deadwood, Hell on Wheels, The Walking Dead, Westworld, but also on "old" Western series such as Gunsmoke and Bonanza. 